\title{
The consequences of Less Favoured Area support: a multi-regional CGE analysis for Poland
}

\author{
Katarzyna Zawalińska ${ }^{a}$, James Giesecke ${ }^{b}$ and Mark Horridge ${ }^{b}$ \\ aIRWiR, Polish Academy of Sciences, ul. Nowy Swiat 72, 00-330 Warsaw, Poland \\ ${ }^{b}$ Centre of Policy Studies, Monash University, Building 11E, Clayton, Victoria 3800, Australia \\ e-mail: kzawalinska@irwirpan.waw.pl
}

\begin{abstract}
On accession to the EU, Poland, one of the most agricultural countries in Europe, became eligible for the Common Agricultural Policy (CAP), which it perceived as a chance to develop its rural economy. However, in constructing its Rural Development Programme 2007-2013, Poland directed the largest funding share to Less Favoured Areas (LFA) - a controversial measure, which has been accused of poor targeting and ineffectiveness. We analyse the economic consequences of LFA support for all 16 Polish regions according to Nomenclature of Territorial Units for Statistics (NUTS2), using a multi-regional computable general equilibrium model with LFA detail.
\end{abstract}

Key words: Common Agricultural Policy Reform, decoupling, regional CGE, Less Favoured Areas, Dutch disease, Poland

\section{Introduction}

The European Commission designates as a "less-favoured area" those territories where agricultural activity is rendered difficult by natural handicaps such as poor climate, steep terrain or barren soil. A region may also be designated less-favoured if continued agricultural activity is threatened by specific economic or environmental handicaps, and it is deemed important to conserve or improve the environment, maintain the countryside or preserve tourism potential (IEEP 2006). The chief policy rationale for the LFA measures of the CAP is that farms operating in areas with natural or other specific constraints generate an on-going risk of agricultural land abandonment. An ostensible aim of the LFA payment scheme is to mitigate this risk. LFA support is channelled through Rural Development Programmes (Pillar 2 of the CAP) in all EU27 countries. Across the EU27, LFA designations are significant, accounting for over a quarter of EU27 agricultural activity. ${ }^{1}$ In Finland, 95.1 per cent of the country's utilised agricultural area (UAA) is classified as LFA, while in Poland 62.5 per cent of UAA is LFA classified (LFA 2012, p. 159). The majority of Member States have provided significant support to the scheme. For example, in Poland and Finland, the scheme represents about 50 per cent of the Pillar 2 budget. At the EU level, the European Agricultural Fund for Rural Development (EAFRD) dedicated $€ 12.6$ billion to the scheme for 2007-2013, corresponding to 13.9 per cent of EAFRD or 32 per cent of Axis 2 (the environmental component of the Rural Development Programmes).

The LFA measure has been under revision since a report by the European Court of Auditors, which criticised it for lack of targeting (OJ 2003). Later reviews of the LFA scheme have also been critical, noting: inconsistencies in the delimitation of LFA areas across countries and regions; unequal treatment of LFA beneficiaries arising from the diversity of LFA criteria across countries and regions; and, poor targeting of the aid (EC 2009a). These criticisms have generated political pressure to revise the LFA measure across the EU and implement a new system from 2014, when the new Rural Development Programs will be implemented. Current CAP reforms foresee changes to the system for classifying LFA over 2014-2020, narrowing eligibility criteria from their present state, a set of over one hundred country-specific criteria, to a set of eight soil and climate conditions (EC 2009b).

While the LFA instrument is under revision (LFA 2012), there is little literature on its economic impact, particularly at the regional level. The existing studies of CAP usually investigate its impact at the country level, not the regional level, while focussing on Pillar 1, and Old Member States. Dixon and Matthews (2006) analysed the impact of the CAP reform on the Irish economy using a multi-sectoral computable general equilibrium (CGE) model, showing that although it re-allocated resources within agriculture, the economy-wide effects were minimal. No regional effects were investigated. More recently, a study of CAP reform using the GTAP model stated that "[...] Rural development spending (Pillar 2) is not modelled because the effects of this class of spending are too complex and uncertain and difficult to value [...]" (Costa et al. 2009).

${ }^{1}$ Excluding mountain areas, LFA regions account for 30 per cent of EU27 agricultural holdings, 31 per cent of the EU27 agricultural labour force and $26 \%$ of EU27 agricultural economic potential (CC 2009). 
Previous papers have studied the LFA program using a number of methods. Schwarz (2010) provides an economy-wide perspective on the LFA's impact on the Scottish economy via a SAM-based approach. Gelan and Schwarz (2008) use a CGE model of the Scottish economy to study the effects of CAP reforms on LFA farming. While their model is economy-wide, their focus is agricultural activities, not regional or national economies. Other studies have focussed on specific features of the LFA, such as: the characteristics of its implementation across countries (Schouten et al. 2009, Klepacka-Kołodziejska 2010); its impact on agricultural efficiency (Lambarraa and Kallas 2009); and its impact on the environment (Lehtonen 2008). Gelan and Schwarz (2008) and Nowicki et al. (2009) study how LFAs have been affected by CAP reform. The CAPRI model offers promising avenues for future research into LFA's economy-wide and regional economic effects. LFA payments are built into the CAPRI model (Witzke and Britz 2010). Recent work has extended CAPRI via a regional CGE interface (Törmä et al. 2010, Britz 2012). This opens the possibility of using the model in the future to study the regional economy-wide effects of LFA support.

Our paper investigates the regional, national and sectoral economic consequences of Poland's LFA scheme. In the context of the existing CAP literature, which emphasises investigation of the national impacts of Pillar 1 measures in Old Member States, our study appears to be the first to investigate the regional impacts of Pillar 2 measure in a New Member State. We investigate how LFA affects land rental prices, use of agricultural land, employment, and agricultural prices and production. We also investigate the indirect effects of LFA support on variables such as employment, GDP and population. Thus our paper elucidates the effectiveness of LFA in achieving one of its objectives, namely, maintaining agricultural activities in the areas under question. Poland presents an interesting case study. First, it is one of the largest agriculture-dependent countries in the EU². Second, Poland has 16 very diverse regions, from predominantly urban and non-agricultural, to predominantly rural and very much dependent on agriculture. Thirdly, LFA in Poland absorbs the highest allocation of European Agricultural Fund for Rural Development (EAFRD) of total LFA support in the EU (Tödtling-Schönhoferet al. 2008), hence we analyse a substantial share of the total EU27 Pillar 2 and LFA budget.

\section{LFA measure in Poland}

Poland has chosen 21 measures for its Rural Development Program (RDP) 2007-2013 (Pillar 2), spreading a fixed budget thinly over many uses. A number of studies have suggested that rural development goals would be easier to achieve if the funds were more concentrated (Zawalińska 2009). Of all 21 Pillar 2 measures planned for 2007-2013 in Poland, LFA is the largest, at 2.45 billion EUR, representing 14.7 per cent of Poland's total Pillar 2 budget. The allocations for the other measures of the 2007-2013 RDP are presented in Table1.

The analysis of the economic, social and environmental situation of rural areas in the National Strategic Plan for 2007-2013 Rural Development (MARD 2006) outlined a number of desirable policy directions for Poland's rural areas. These included facilitating the outflow of farmers to other occupations, creating non-agricultural jobs in rural areas, increasing agricultural labour productivity, and improving quality of life in rural areas. Judged against these policy aims, the high proportion of RDP funds allocated to LFA may seem problematic. Indeed, as we shall find in section on the national, sectoral, and regional effects of LFA, the indirect outcomes of the LFA program run counter to these aims, retaining labor in agriculture and adversely affecting employment in non-agricultural sectors.

According to the latest available classification, LFA covers 62.5 per cent of Poland's UAA (LFA 2012, p. 159). LFA support consists of annual flat rate payments (compensatory allowances) per hectare of LFA-designated agricultural land remaining in agricultural use.

The regional distribution of LFA support is determined by the delimitation of the LFA areas, based on several criteria describing natural and socio-economic conditions. We assume that the structure of the regional distribution over 2007-2013 is similar to that of the previous budgetary period, since both the LFA definitions and the conditions they describe have changed little. Only the budgetary amounts per region differ, reflecting the fact that the total allocations have changed (see Table 2).

\footnotetext{
${ }^{2}$ In Poland, rural areas account for 93.2 per cent of total land area, and 38.6 per cent of total population. The agricultural sector accounts for approximately 15 per cent of employment (FDPA 2010).
} 
Table 1. Annual amounts and shares of Pillar 2 measures, sorted by size

\begin{tabular}{|c|c|c|c|c|c|c|c|}
\hline No. & Short name of measure & $\begin{array}{c}\text { Millions } \\
\text { EUR }\end{array}$ & $\%$ & No. & Short name of measure & $\begin{array}{c}\text { Millions } \\
\text { EUR }\end{array}$ & $\%$ \\
\hline 1 & LFA (Less favoured areas) & 350 & 14.7 & 12 & Young Farmers support & 56.3 & 2.4 \\
\hline 2 & Agri-Environmental programs & 329.3 & 13.9 & 13 & Technical Assistance & 47.6 & 2 \\
\hline 3 & Early Retirement & 293.1 & 12.3 & 14 & Advisory & 46.9 & 2 \\
\hline 4 & Modernization of farms & 238.5 & 10 & 15 & Diversification & 46.3 & 1.9 \\
\hline 5 & Basic Services & 197.2 & 8.3 & 16 & Restoring Forest & 20 & 0.8 \\
\hline 6 & Added Value & 147.4 & 6.2 & 17 & Producer Groups & 18.8 & 0.8 \\
\hline 7 & Micro-Enterprises & 137.2 & 5.8 & 18 & Food quality systems & 13.4 & 0.6 \\
\hline 8 & Afforestation & 93.4 & 3.9 & 19 & Training & 5.4 & 0.2 \\
\hline 9 & Development of Infrastructure & 80.4 & 3.4 & 20 & Information and Promotion & 4 & 0.2 \\
\hline 10 & Village Renewal & 79 & 3.3 & 21 & LEADER $(1+2+3)$ & 112.6 & 4.7 \\
\hline 11 & Semi-subsistence farms' support & 59 & 2.5 & & Total & 2375.8 & 100 \\
\hline
\end{tabular}

Source: Based on RDP 2007-2013 (2007)

Table 2. Regional structure of annual LFA payments in Poland (millions $€$ )

\begin{tabular}{|c|c|c|c|c|c|}
\hline & & $\begin{array}{l}\text { Regional shares } \\
\text { of LFA budget* }\end{array}$ & Millions EUR & $\begin{array}{c}\text { Population } \\
2003 \text { Millions }\end{array}$ & $\begin{array}{l}\text { Main } \\
\text { Town }\end{array}$ \\
\hline 1 & Dolnośląskie & 0.037 & 12.95 & 2.9 & Wrocław \\
\hline 2 & Kujawsko-Pomorskie & 0.053 & 18.55 & 2.1 & Bydgoszcz \\
\hline 3 & Lubelskie & 0.067 & 23.45 & 2.2 & Lublin \\
\hline 4 & Lubuskie & 0.030 & 10.5 & 1.0 & Gorzów Wlkp. \\
\hline 5 & Łódzkie & 0.075 & 26.25 & 2.6 & Lódź \\
\hline 6 & Małopolskie & 0.040 & 14 & 3.3 & Kraków \\
\hline 7 & Mazowieckie & 0.185 & 64.75 & 5.1 & Warsawa \\
\hline 8 & Opolskie & 0.008 & 2.8 & 1.1 & Opole \\
\hline 9 & Podkarpackie & 0.032 & 11.2 & 2.1 & Rzeszów \\
\hline 10 & Podlaskie & 0.134 & 46.9 & 1.2 & Białystok \\
\hline 11 & Pomorskie & 0.049 & 17.15 & 2.2 & Gdańsk \\
\hline 12 & Śląskie & 0.015 & 5.25 & 4.7 & Katowice \\
\hline 13 & Świętokrzyskie & 0.028 & 9.8 & 1.3 & Kielce \\
\hline 14 & Warmińsko-Mazurskie & 0.074 & 25.9 & 1.4 & Olsztyn \\
\hline 15 & Wielkopolskie & 0.128 & 44.8 & 3.4 & Poznań \\
\hline \multirow[t]{2}{*}{16} & Zachodniopomorskie & 0.045 & 15.75 & 1.7 & Szczecin \\
\hline & TOTAL & 1 & 350 & 38.2 & \\
\hline
\end{tabular}

Source: Own calculations based on RDP 2007-2013 (2007) and ARMA (2009)

Note: *Assumed to be the same as in 2004-2006

The regions with the highest shares of Less Favoured Area support are: Mazowieckie - the capital region, Podlaskie - a region on Poland's Eastern border with more than 50 per cent of the rural population working in an agricultural sector dominated by middle size family farms, and Wielkopolskie - a region close to the Western border characterised by modern and competitive large farm agriculture. This is suggestive of the LFA delimitation criteria being less suited to Poland, since the outcome is for support to be spread widely across different types of regions, while leaving some regions highly disadvantaged by geographical structures such as slope and mountainous terrain (such as Podkarpackie, Małopolskie and Świetokrzyskie) receiving small shares of the total support. ${ }^{3}$

\footnotetext{
${ }^{3}$ Gorton et al. (2009) make the more general case that the Common Agricultural Policy is ill-suited to the rural circumstances of Central and Eastern Europe.
} 


\section{POLTERM: a bottom-up multi-regional model of Poland Overview of POLTERM: a Polish implementation of the TERM model}

POLTERM is an implementation of the TERM model (Horridge et al. 2005) to the Polish economy. ${ }^{4}$ It is a bottomup multi-regional CGE model that explicitly captures the behaviour of industries, households, investors, government and exporters at the regional level. The theoretical structure of TERM follows the familiar neoclassical pattern common to many applied general equilibrium models. Producers in each region are assumed to minimize production costs subject to industry-specific production technologies. A representative household in each region purchases goods in order to obtain the optimal bundle in accordance with its preferences and disposable income. ${ }^{5}$ In the short-run, investors allocate new units of capital to regional industries on the basis of expected rates of return. Long-run capital supply to each regional industry is elastic at given rates of return. Commodity-specific export demands for each region are modelled via constant elasticity demand functions.

In TERM, economic agents decide on the geographical source of their purchases according to relative prices and a nested structure of substitution possibilities. The first choice facing the purchaser of a unit of a particular commodity is whether to buy one that has been imported from abroad or one that has been produced in Poland. If a Polish product is purchased, a second decision is made, at the level of the destination region, as to the particular Polish origin regions from which the commodity will be sourced. TERM contains a large database that tracks flows of international and interregional purchases of each commodity from each region of origin to each destination region. It also records the associated margin payments and the geographical location of the suppliers of those margins. In the case of each regional user, account is also taken of the taxes payable on the purchase.

\section{POLTERM data sources}

The Polish version of TERM models 86 economic activities in the 16 NUTS2 regions. ${ }^{6}$ The sectoral dimensions of POLTERM have been tailored for rural and agricultural analyses. In its full disaggregation, the model has 20 sectors related to agricultural production and 8 to food production. In this study, for simplicity we aggregated our database to 11 agricultural activities, 6 food products, and 16 remaining sectors). ${ }^{7}$ The benchmark year for the model is 2005, with the model's primary data source being the 2005 Polish input-output tables (see EUROSTAT 2011 and the Polish Main Statistical Office GUS 2009a, b). ${ }^{8}$ EU Agricultural subsidies are included in the official 2005 tables as "other net taxes on production". Hence, our initial model calibration, which is based on the official 2005 inputoutput data, includes CAP payments for that year.

In moving from the national input-output data described by GUS (2009a) to the regional input-output system required by TERM, we used the methods described in Horridge (2011). These use data on the regional distribution of industry output and final demands to infer a set of regional input-output tables that mostly display the same industry technology and final demand composition as the national table. From the regional tables we can deduce regional production, use and net exports of each commodity. A matrix $\operatorname{TRADE}(c, r, d)$ shows how much of commodity $c$ used in region $d$ is produced in region $r$. To construct this matrix we assume (a) a strong local bias in sourcing, and (b) regions import more from closer regions. For (b) a gravity assumption is used: trade is inversely proportional to a power of distance (between the main towns of each region, listed in Table 2), with a higher exponent for heavy or bulky goods. In defence of these assumptions we note (i) that they are applied at the original, detailed level of industry disaggregation, where the 'same technology everywhere' assumption is more plausible, and where net export figures give more clues about inter-regional trade; and (ii) for some commodities we assume that goods from different regions are good substitutes - in this case the pattern of the TRADE matrix does not affect results much.

\footnotetext{
${ }^{4}$ Previous implementations of the TERM model include e.g. Finnish VERM model - see Honkatukia et al. (2009) or Kinnunen et al. (2009).

${ }^{5}$ Household preferences are assumed to be Klein-Rubin, generating a household demand system of the LES form.

${ }^{6}$ As defined by Eurostat, "the NUTS classification (Nomenclature of territorial units for statistics) is a hierarchical system for dividing up the economic territory of the EU" (see http://epp.eurostat.ec.europa.eu/portal/page/portal/nuts_nomenclature/introduction). For Poland, the sixteen NUTS2 regions conform to the sixteen regions of Poland's provincial government level.

7 See Table 5.

${ }^{8}$ At the time of writing, the most recent Polish input-tables were for 2005. Publication of the next input-output tables (for 2010) is expected at the end of 2013
} 
The CAPRI database was an important source of information for our disaggregation of the agricultural sector, both in terms of its sectoral and regional detail. ${ }^{9}$ We used CAPRI data for two purposes. First, we used CAPRI data as the basis for our regionalisation of the national agriculture sector, as embodied in the official 2005 national inputoutput table, across 16 NUTS2 regional agricultural sectors. Second, we used the CAPRI data as the basis for disaggregating the single agricultural and food processing sectors in the GUS (2009a) Polish input-output table into 11 agricultural and 6 food processing industries respectively.

We obtained data on LFA payments by NUTS2 regions from the Agency for Reconstruction and Modernization of Agriculture, the authority responsible for the Pillar 2 monitoring database in Poland (ARMA 2009). Data on land taxes by NUTS2 regions paid by agriculture were available from Poland's Main Statistical Office (GUS 2005, p. 632). We obtained data delineating LFA land by NUTS2 region in Poland from IUNG (Institute of Soil Science and Land Cultivation) (MARD 2009).

As an EU Member State, Poland has an open labour market with the rest of the EU. Indeed since EU accession, the level of Polish emigration has been substantial. In modelling Poland's labour market in POLTERM, we allow the size of the in-Poland workforce to respond endogenously to movements in the Polish real wage, with an elasticity of $0.10 .^{10}$

\section{Modelling the LFA measure in POLTERM}

LFA payments take the form of an annual grant per hectare of LFA land used for agricultural purposes. From a modelling perspective, this can be viewed as a per hectare LFA land rental subsidy. Any given Polish region, $r$, will tend to have producers cultivating both LFA and non-LFA land areas but in different proportions. Hence in POLTERM, we distinguish these two types of land. The ostensible purpose of LFA funding is to increase farmer incentives to farm more LFA land than they would otherwise (as discussed above). Implicit in this aim is a belief that agricultural activity in LFA areas would decline in the absence of the support. To model this, we allow the supply of LFA land to respond endogenously to movements in its post-tax rental price as suggested in the literature (Latruffe and Le Mouel 2009). We set our central value for the elasticity of supply of LFA land with respect to post-tax rental ( $\eta_{r}^{(S) L F A}$ ) at 0.2 , In using this value, we note that Van Meijl et al. (2006) places the land supply elasticity in the EU within the range 0.01 to 0.2. This supports a similar range found by Abler (2003), who put the value between 0.0 and 0.2. In the CAPRI model, Poland's land supply elasticity is set at 0.15 (Britz and Witzke 2008). The LEITAP Model sets the same elasticity at 0.475 (Woltjer et al. 2011). As an approximate mid-point in the range of available estimates, we take 0.2 as our value for the land supply elasticity. For non-LFA land, we set the corresponding elasticity $\left(\eta_{r}^{(S) n o n-L F A}\right)$ at 0 , as there is very little fallow land in Poland that can be easily turned into arable non-LFA land.

\footnotetext{
${ }^{9}$ CAPRI (Common Agricultural Policy Regionalised Impact Modelling System), developed at the University of Bonn, is a complete, closed and consistent agricultural data base for NUTS2 regions of the EU27+. The database includes 50 agricultural activities, based on Economic Accounts, farm-market balances and unit value prices at the national level for about 60 products and 35 inputs. The model is described in detail at the CAPRI website http://www.capri-model.org/dokuwiki/doku.php, accessible on 24 May 2013.

${ }^{10}$ To our knowledge, there are no econometric estimates of the elasticity of Poland's workforce with respect to the Polish real wage relative to the EU real wage. For the simulations reported in this paper, we set this elasticity at 0.10 . We justify this as follows. In the years $2004-08$, $2.2 \mathrm{~m}$. Polish workers emigrated (GUS 2009c, p.2). This represented approximately $9 \%$ of the Polish workforce of $24.6 \mathrm{~m}$. (GUS-BDR 2009). Prior to EU accession in 2004, opportunities for Polish labour to work in the EU were limited. At the time of EU accession in 2004, the average Polish wage was 2290 zloty (GUS 2010), the equivalent of approximately 573 EUR. The main destination for Polish emigrant labour post-accession was the UK (GUS 2009c, p.3). There, the majority of Polish workers earned the minimum UK wage of 1084 EUR (EUROSTAT 2004 , p. 2). As such, Poland's EU accession made available, to workers willing to emigrate, wages 90 per cent higher than those possible in Poland. This generated a 9 per cent reduction in the Polish workforce. So our working age population supply elasticity of 0.10 is consistent with this historical outcome, according to the formula $-9 /((573-1084) / 573 * 100)=0.10$.
} 


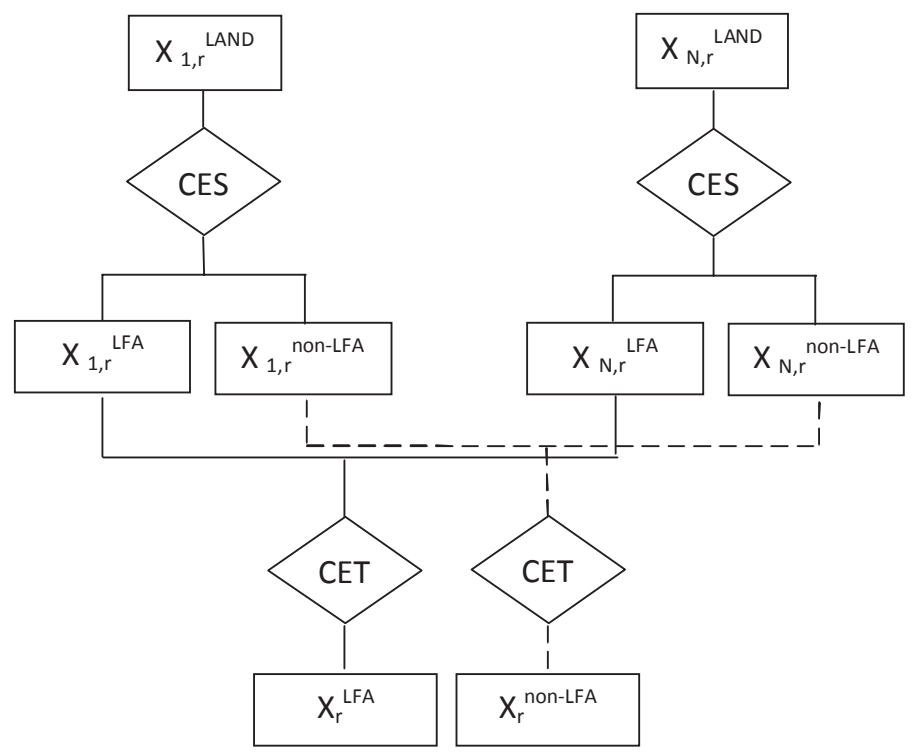

Fig. 1. Agricultural land supply and agricultural land demand in POLTERM Source: Authors' elaboration

Figure 1 describes the modelling of regional agricultural land supply and land demand. At the bottom level of this diagram, regional endowments of LFA and non-LFA land ( $X_{r}^{L F A}$ and $X_{r}^{\text {non-LFA }}$ respectively) are potentially supplied to agricultural industries $1-\mathrm{N}$ in region $r$. Land supply functions across land users are modelled via constant elasticity of transformation (CET) functions. We assume that landowners seek to maximise land rentals subject to constrained land transformation possibilities described by CET functions. At the top level of Figure 1, users of agricultural land face imperfect substitution possibilities between LFA and non-LFA land, which are described by constant elasticity of substitution (CES) functions. In modelling the behaviour of users of agricultural land, we assume they minimise the cost of acquiring a given input of land by substituting across land types, subject to the constraints posed by the CES functions. Equations (E1) - (E5) in Table 3 set out, in percentage change form, the system of supply, demand and unit-cost functions arising from revenue-maximising and cost-minimising behaviour under the production technology assumed in Fig. $1 .{ }^{11}$ Equations (E1) and (E2) describe the operation of the land supply nests at the bottom level of Fig. 1. In (E1), the percentage change in the supply of land type $n$ to agricultural user $j$ in region $r\left(x_{j, r}^{(S) n}\right)$ depends on both the availability of land type $n$ in region $r\left(x_{r}^{(S) n}\right)$ and the relative land rental received when supplying to user $j\left(p_{j, r}^{n}-p_{r}^{n}\right) .{ }^{12}$ The average rental on land type $n$ in region $r\left(p_{r}^{n}\right)$ is defined by (E2) as the revenue-share-weighted sum of the percentage changes in rentals received from each user of land type $n$ in region $r$. Equations (E3) and (E4) describe the operation of the land demand nests at the top level of Fig. 1. In (E3), the percentage change in the demand for land type $n$ by agricultural user $j$ in region $r\left(x_{j, r}^{(D) n}\right.$ ) depends both on the demand for land in general by such users $\left(x_{j, r}^{\text {Land }}\right)$ and the relative user price of land type $n\left(p_{j, r}^{n}-p_{j, r}^{\text {Land }}\right)$. The percentage change in the average cost of agricultural land to user $j$ in region $r$ is defined by (E4) as the cost share weighted sum of the percentage changes in the rental prices of the LFA and non-LFA land employed by user $j, r$. Together, (E1) and (E3) define percentage changes in user-, region- and land-specific land supply and demand. Equation (E5) imposes a market clearing condition on these user-, region- and land-specific land markets, thus allowing endogenous determination of land rental prices $\left(p_{j, r}^{n}\right)$. Equation (E6) defines the percentage change in net land rentals received by land owners. In the original levels form, (E6) expresses net land rentals as the product of pre-subsidy land rentals and the power (one plus the rate) of land subsidy. In (E6), the percentage change in the land subsidy appears as $s_{r}^{n}$. It is $s_{r}^{n}$ that we shock when modelling LFA payments, as discussed in further sections. In calculating values for $s_{r}^{n}$, we obtain data on region-specific values for LFA payments from (ARMA 2009). Equation (E7) defines the supply of land type $n$ in region $r$. Under (E7), the percentage change in the supply of land type $n$ in region $r$ is positively related to the land's real post-subsidy rental rate. The strength of the land supply response to changes in the post-subsidy rental rate depends on the supply elasticity $\eta_{r}^{(S) n}$. As discussed in the introduction to this section, we set $\eta_{r}^{(S) L F A}=0.2$ and $\eta_{r}^{(S) \text { non-LFA }}=0$.

\footnotetext{
${ }^{11}$ For a formal derivation of these percentage change forms from economic problems such as those described by Fig. 1, see Dixon et al. (1992). In particular, see Dixon et al. (1992, p. 128-133) for discussion of the CET function and Dixon et al. (1992, p. 124-126) for discussion of the CES function.

${ }^{12}$ Because the subsidy rate in any region is the same across all uses of LFA land, in (E1) we can assume that land supplies to activities respond to pre-subsidy rental prices.
} 
Table 3. Percentage change form of the equations underlying Figure 1.
(E1) $\quad x_{j, r}^{(S) n}=x_{r}^{(S) n}+\phi_{r}^{n}\left(p_{j, r}^{n}-p_{r}^{n}\right)$
$(n \in \mathrm{LANDTYPE}),(j \in \mathrm{AGRIND}),(r \in \mathrm{REGION})$
Average rental price of land $p_{r}^{n}=\sum_{j} B_{j, r}^{n} p_{j, r}^{n}$
$(n \in \mathrm{LANDTYPE}),(r \in \mathrm{REGION})$
Demand function for land cultivated on LFA areas under activity $\mathrm{j}$ in region $\mathrm{r}$
$x_{j, r}^{(D) n}=x_{j, r}^{\text {Land }}-\sigma_{j, r}\left(p_{j, r}^{n}-p_{j, r}^{\text {Land }}\right)$
$(n \in \mathrm{LANDTYPE}),(j \in \mathrm{AGRIND}),(r \in \mathrm{REGION})$
(E4) $\quad$ Average user price of land $p_{j, r}^{\text {Land }}=\sum_{n \in L A N D T Y P E} S_{j, r}^{n} p_{j, r}^{n}$
$(j \in \mathrm{AGRIND}),(r \in \mathrm{REGION})$
(E5) Land market clearing conditions $x_{j, r}^{(D) n}=x_{j, r}^{(S) n}$
$(n \in \mathrm{LANDTYPE}),(j \in \mathrm{AGRIND}),(r \in \mathrm{REGION})$
Net land rentals received by landowners
(E6)
$\operatorname{pps}_{r}^{n}=p_{r}^{n}+s_{r}^{n}$
$(n \in \mathrm{LANDTYPE}),(r \in \mathrm{REGION})$
(E7)
Land supply functions
$x_{r}^{(S) n}=\eta_{r}^{(S) n}\left(p p s_{r}^{n}-p_{r}^{G D P}\right) \quad(n \in \mathrm{LANDTYPE}),(r \in \mathrm{REGION})$

Land supply response functions

LANDTYPE (LFA land, non-LFA land).

REGION (regions 1 through 16. See Table 6).

AGRIND (Wheat, Rye, Barley, Other cereals, Oil seeds, Vegetables and fruit, Other crops, Other animals, Pigs, Poultry, Cattle).

where:

$x_{r}^{(S) n} \quad$ is the percentage change in the supply of land type $n$ in region $r$;

$\eta_{r}^{(S) n} \quad$ is the elasticity of supply of land type $n$ with respect to its real post-tax rental price;

$\operatorname{pps}_{r}^{n} \quad$ is the percentage change in the post-subsidy rental price of land type $n$ in region $\mathrm{r}$.

$p_{r}^{G D P}$ is the percentage change in the regional GDP deflator for region $r$.

$p_{r}^{n} \quad$ is the percentage change in the pre-subsidy rental price of land type $n$ in region $r$;

$s_{r}^{n} \quad$ is the percentage change in the power (1 plus the rate) of the land rental subsidy on land type $n$ in region $r$;

$x_{j, r}^{(S) n} \quad$ is the percentage change in the supply of land type $n$ in region $r$ to agricultural industry $j ;$

$\phi_{r}^{n} \quad$ is the elasticity of transformation of land type $n$ in region $r$ between alternative agricultural uses $j$;

$p_{j, r}^{n} \quad$ is the percentage change in the price faced by agricultural producer $j$ in region $r$ for land type $n$;

$B_{j, r}^{n} \quad$ is the share of type $n$ land rentals in region $r$ generated by agricultural industry $j$;

$x_{j, r}^{(D) n} \quad$ is the percentage change in demand for land type $n$ by agricultural user $j$ in region $r$;

$x_{j, r}^{\text {Land }} \quad$ is the percentage change in demand for land (undistinguished by type) by agricultural industry $j$ in region $r$;

$\sigma_{j, r} \quad$ is the elasticity of substitution between different land types faced by agricultural industry $j$ in region $r$;

$p_{j, r}^{\text {Land }} \quad$ is the percentage change in the average user price of land faced by agricultural industry $j$ in region $r$;

$S_{j, r}^{n} \quad$ is the share of industry $(j, r)^{\prime}$ s total land costs represented by rentals on agricultural land type $n$. 


\section{Simulation design: model closure and perturbed exogenous variables}

LFA payments will have immediate impacts on rates of return, regional wage relativities and output prices. Our aim is to investigate the economic consequences of LFA payments after all market adjustments to these immediate LFA-induced relative price changes have taken effect. That is, our concern is long-run. Hence we use a closure of POLTERM that is a variant of the standard long-run TERM closure. ${ }^{13}$ This closure defines a long-run solution year with the following characteristics:

(i) Investors in each industry in each region have had sufficient time to adjust regional industry capital stocks in response to the policy change. Thus changes in demand for capital are manifest as changes in capital supply, not as changes in rental rates. We implement this by allowing capital to be in elastic supply to each regional industry at exogenous rates of return.

(ii) Supply of LFA land is positively related to post-tax land rental rates. Supply of non-LFA land is exogenous.

(iii) We assume that long-run national employment is weakly positively related to the Polish real wage. This reflects Poland's open labour market with the EU. As discussed in section Overview of POLTERM, we calibrate the labour supply elasticity to reflect Poland's emigration experience following EU accession.

(iv) Since our focus is long-run, we allow labour to move between regions in response to regional wage differentials. However, we recognise that household locational preferences constrain labour movements even in the long-run. We model this by allowing regional employment to be endogenous, but sticky. Stickiness in regional labour supply is achieved by allowing the change in the gap between the regional wage and the national wage to be weakly positively related to the movement in regional employment. In terms of our model results, this closure has the effect of ensuring that long-run regional labour-market pressures mostly appear as movements in regional employment, together with some limited movement in relative regional wage rates.

(v) We assume that the desired rate of capital accumulation in each regional industry in the long-run solution year is independent of the policy shock. We implement this via exogenous determination of regional industry investment/capital ratios. With movements in long-run regional industry capital stocks largely determined by the first closure assumption above, this effectively links long-run movements in regional industry investment to movements in regional industry capital stocks. National investment is determined as the sum of regional industry investments.

(vi) We constrain movements in the long-run balance of trade to reflect two features of solution year net foreign financing: net receipts of LFA payments by Poland, and the need to finance changes in solution-year capital stocks. Ceteris paribus, LFA payments received by Poland allow the balance of trade to move towards deficit. In financing the solution year capital stock, we assume that 60 per cent of capital rentals arising from new capital are sent to foreign capital owners via an appropriate movement towards balance of trade surplus. ${ }^{14}$ With the solution year balance of trade constrained in this way, we allow private and public consumption to be determined endogenously. This closure can be interpreted as allowing domestic consumption to move with national income, where LFA payments represent an addition to national income, and servicing of foreign financed capital accumulation a gross subtraction from national income. Subject to this national constraint, we assume regional private consumption is a fixed proportion of regional income.

(vii) We assume that long-run regional public consumption spending will follow movements in the long-run regional distribution of economic activity. Regions in which long-run population, employment and consumption are rising (falling) receive a rising (falling) share of national public consumption spending. We model this via exogenous determination of region-specific ratios of real public consumption spending to real private consumption spending.

Our shocks to the POLTERM model are region-specific LFA payments. The aggregate value of Polish LFA payments under CAP funding round 2007-13 is reported in row 1 of Table 1 . The regional distribution of these payments is reported in Table 2. These values are used to calibrate shocks to region-specific land subsidy variables, represented by $s_{r}^{n}$ in equation (E6).

\footnotetext{
${ }^{13}$ Our closure departs from the standard long-run TERM closure in two ways. First, via assumption (ii) above, and equation (E7) of Table 3 , we override the standard assumption of exogenous land supply. Second, via assumption (iii) above, we override the standard assumption of exogenous national employment.

${ }^{14}$ The simulation we report in Section $V$ generates, over a five year period, sufficient domestic savings to finance approximately 40 per cent of the solution year change in the capital stock.
} 


\section{The national, sectoral and regional effects of LFA support}

We discuss the national, sectoral and regional economic consequences for Poland of LFA support payments. Our interpretation of the POLTERM results is comprised of a sequence of cross-referenced discussions, each of which relies on familiar economic mechanisms, not details of POLTERM's theoretical structure.

\section{The impact of LFA support on the national macroeconomy}

Table 4 reports the effects of LFA support on selected national macroeconomic indicators. At the national level, Poland's annual receipt of PLN 1.2 b. of LFA funds represents approximately 18 per cent of the value of pre-LFA land rentals accruing to LFA-designated land. ${ }^{15}$ We model the LFA support as a per-hectare subsidy to landowners (see section on POLTERM data above).

Table 4. Impact of LFA support at the national level ${ }^{(a)}$

\begin{tabular}{|c|c|c|c|}
\hline National macroeconomic indicator: & $\%$ change & National macroeconomic indicator: & $\%$ change \\
\hline 1. Real GDP at market prices & 0.07 & 16. Nominal exchange rate (foreign currency/PLN) & 0 \\
\hline 2. Aggregate employment & 0.02 & 17. Consumption deflator (private \& public) & 0.06 \\
\hline 3. Aggregate capital stock & 0.06 & 18. Private consumption price deflator & 0.04 \\
\hline 4. Aggregate land supply - all land & 1.19 & 19. Public consumption price deflator & 0.13 \\
\hline 5. Aggregate land supply - LFA land & 2.26 & 20. Investment price deflator & 0.05 \\
\hline 6. Aggregate land supply - non-LFA land & 0 & 21. GDP deflator (market prices) & 0.08 \\
\hline 7. Real consumption (private $\&$ public) & 0.2 & 22. GDP deflator (factor cost) & 0.08 \\
\hline 8. Real private consumption & 0.19 & 23. Real wage & 0.16 \\
\hline 9. Real public consumption & 0.22 & 24. Rental price of capital & 0.05 \\
\hline 10. Real investment & 0.06 & 25. Average user price of land - all land & -2.2 \\
\hline 11. Real GNE & 0.17 & 26. Average user price of land - LFA land & -6.02 \\
\hline 12. Real exports & -0.23 & 27. Average user price of land - non-LFA land & 2.18 \\
\hline 13. Real imports & 0.07 & 28. Average owner price of land - all land & 7.33 \\
\hline 14. Terms of trade & 0.06 & 29. Average owner price of land - LFA land & 11.8 \\
\hline 15. Real exchange rate & 0.08 & 30. Average owner price of land - non-LFA land & 2.18 \\
\hline
\end{tabular}

Source: Authors' calculations using POLTERM. Note: ${ }^{(a)}$ Results reported as the annual percentage change away from where the economy would otherwise have been in the absence of LFA support.

In our macroeconomic results, this direct effect of LFA payments is manifested as a 17.8 percentage point gap $(=11.8-6.0)$ between the LFA land rental rate received by landowners (row 29) and the LFA land rental rate paid by land users (row 26). LFA payments produce a fall in the user-price of LFA land (row 26) because we allow the supply of LFA land to be a positive function of the post-tax rental value of LFA land (see equation E7 above).

As discussed in section on POLTERM data above, we set the LFA land supply elasticity at 0.2. Hence, with the posttax rental price of LFA land rising by 11.8 per cent (row 29), the aggregate supply of LFA land rises by 2.26 per cent (row 5). As discussed in section on modelling the LFA above, our land use theory allows agricultural producers to substitute between LFA and non-LFA land. The user-price of LFA land must fall (row 26) to induce land users to absorb the increase in LFA land supply.

For a given level of employment, the increase in the supply of agricultural land (see above) causes the marginal physical product of labour to rise. This rise in the marginal physical product is reinforced by a rise in the capital stock (row 3, to be explained below). The increase in the marginal physical product of labour translates into a rise in the value of the marginal product of labour, a rise that is reinforced by an improvement in the terms of trade (row 14, to be explained below). The rise in the terms of trade increases the ratio of the GDP deflator to the consumption deflator (rows 21 and 17), strengthening the tendency towards real wage increase generated by the rise in the marginal physical product of labour. The rise in the value of the marginal product of labour accounts for the movement in the real wage, which rises by 0.16 per cent relative to what it would otherwise have been (row 23).

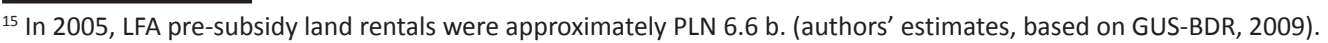


As discussed in section on POLTERM data above, recognising that Poland has an open labour market with much of the EU, we allow Polish labour supply to vary with the real wage. This accounts for the small rise in Polish employment (row 2).

As discussed in section on simulation design above, we assume Poland can obtain capital at given rates of return. With land supply and employment higher than basecase, for a given level of capital, the marginal physical product of capital must rise. The rise in the terms of trade causes the ratio of the GDP deflator to the investment deflator to rise (rows 21 and 20). With the terms of trade higher than basecase, for a given level of capital, the value of the marginal physical product of capital must rise. However, with rates of return exogenous, scope for the value of the physical marginal product of capital to rise is limited. Hence, the capital stock must expand relative to basecase (row 3). The LFA payments induce increases in aggregate land use, employment and capital. This accounts for the increase in real GDP relative to what it would otherwise have been (row 1).

The increase in national real consumption (rows 8 and 9) is substantially higher than the increase in real GDP (row 1). This reflects a rise in real (CPI-deflated) national income relative to real GDP. Real national income rises by more than real GDP for two reasons. First, the terms of trade improves relative to what it would otherwise have been (see below). Second, and more importantly, the LFA funds received by Poland are financed almost entirely by the rest of the EU, and thus represent a net rise in Polish national income. Aggregate real consumption rises by 0.2 per cent (row 7). This is comprised of a 0.19 per cent rise in private consumption (row 8 ) and a 0.22 per cent rise in public consumption (row 9). The larger increase in public consumption relative to private consumption is due to differences across regions in the ratio of public to private consumption.

As discussed in section on simulation design, we assume that solution year investment/capital ratios by regional industry are exogenous. As such, the percentage change in real investment for each regional industry is the same as the percentage change in its capital stock. At the national level, this is reflected in a similar outcome for national real investment (row 10) as the national capital stock (row 3).

The outcome for real investment (+0.06 per cent), is quite close to the outcome for real GDP (+0.07 per cent). However the outcome for national real consumption (+0.2 per cent) substantially exceeds the outcome for real GDP. Together, the outcomes for real investment and real consumption generate a rise in real GNE (row 11) that exceeds the outcome for real GDP. With the real GNE outcome exceeding the real GDP outcome, the real balance of trade must move towards deficit. This accounts for the contraction in real export volumes (row 12) and expansion in real import volumes (row 13).

The movement in export volumes and import volumes implicit in the movement towards balance of trade deficit requires a rise in the price of Polish goods relative to foreign goods. That is, it requires the real exchange rate to appreciate (row 15), making exports dearer in foreign markets, and Polish goods relatively more expensive than competing imports within the domestic Polish market.

In POLTERM, commodity-specific export volumes are modelled as inversely related to commodity-specific foreign currency prices. The contraction in export volumes thus requires a rise in foreign currency export prices. This accounts for the rise in the terms of trade (row 14).

\section{The impact of LFA support on national industrial outcomes}

Table 5 reports national results for output by sector. The largest beneficiaries of the LFA funds are agricultural industries (rows 1-11, Table 5). This reflects the expansion in LFA land generated by the LFA funds. Food processing industries (rows 15-20, Table 5) are indirect beneficiaries of the expansion in agricultural land supply. By lowering the prices of agricultural output, expansion of agricultural production stimulates output of food processing industries by lowering input costs. At the same time, food processing industries receive a demand-side fillip to their output via the expansion in real household consumption spending.

Expansion in real consumption, both private and public, also accounts for expansion in the output of such industries as hotels and restaurants (row 26), dwellings (row 29), education (row 30), public administration (row 31), health (row 32) and other services (row 33). Note that traded goods sectors, such as forestry (row 12), mining (row 14) and non-food manufacturing (row 21) are adversely affected by Poland's receipt of LFA payments. This reflects the appreciation of the real exchange rate. 
Table 5. Impact of LFA support on output by sector

\begin{tabular}{lc|lc}
\hline Sector & $\begin{array}{c}\text { Percentage } \\
\text { change in } \\
\text { output }\end{array}$ & Sector & $\begin{array}{c}\text { Percentage } \\
\text { change in } \\
\text { output }\end{array}$ \\
\hline 1. Wheat & 0.35 & 18. Other food products & 0.14 \\
2. Rye & 0.42 & 19. Beer manufacturing & 0.16 \\
3. Barley & 0.34 & 20. Other beverages & 0.27 \\
4. Other cereals & 0.38 & 21. Other manufacturing & -0.13 \\
5. Oil seeds & 0.33 & 22. Electricity (coal generated) & 0.06 \\
6. Vegetables and fruit & 0.4 & 23. Other electricity & 0.06 \\
7. Other crops & 0.38 & 24. Construction & 0.06 \\
8. Other animals & 0.46 & 25. Trade & 0.03 \\
9. Pigs & 0.36 & 26. Hotels and restaurants & 0.14 \\
10. Poultry & 0.35 & 27. Transport & 0 \\
11. Cattle & 0.4 & 28. Finance & 0.03 \\
12. Forestry & -0.01 & 29. Dwellings & 0.1 \\
13. Fishing & 0.12 & 30. Education & 0.18 \\
14. Coal, ore and other mining & -0.02 & 31. Public administration & 0.21 \\
15. Beef meat manufacturing & 0.13 & 32. Health & 0.21 \\
16. Pork meat manufacturing & 0.11 & 33. Other services & 0.11 \\
17. Dairy products & 0.11 & & \\
\hline
\end{tabular}

Source: Results of the POLTERM model. Regional industry results aggregated to the national level.

\section{The impact of LFA support on Poland's regional economies}

The chief determinant of relative regional GDP outcomes is the relative importance of LFA funding expressed as a share of regional GDP (Fig. 2). LFA funding as a share of regional GDP is reported in the first column of Table 6, while Figure 2 reports POLTERM results for real regional GDP outcomes (see also Map 1). It also reports a predicted regional real GDP outcome based on a regression equation estimated by regressing the POLTERM results for real regional GDP (column 2, Table 6) against the ratio of regional LFA receipts to regional GDP (column 1, Table 6). In Figure 2 we find the predicted real GDP outcomes closely match the POLTERM real regional GDP outcomes. An exception is Mazowieckie. The POLTERM real GDP result for this region is approximately twice that predicted by the regression equation. This reflects the region's strong inter-regional trade links with Podlaskie, the region receiving the highest level of LFA payments as a proportion of regional GDP.

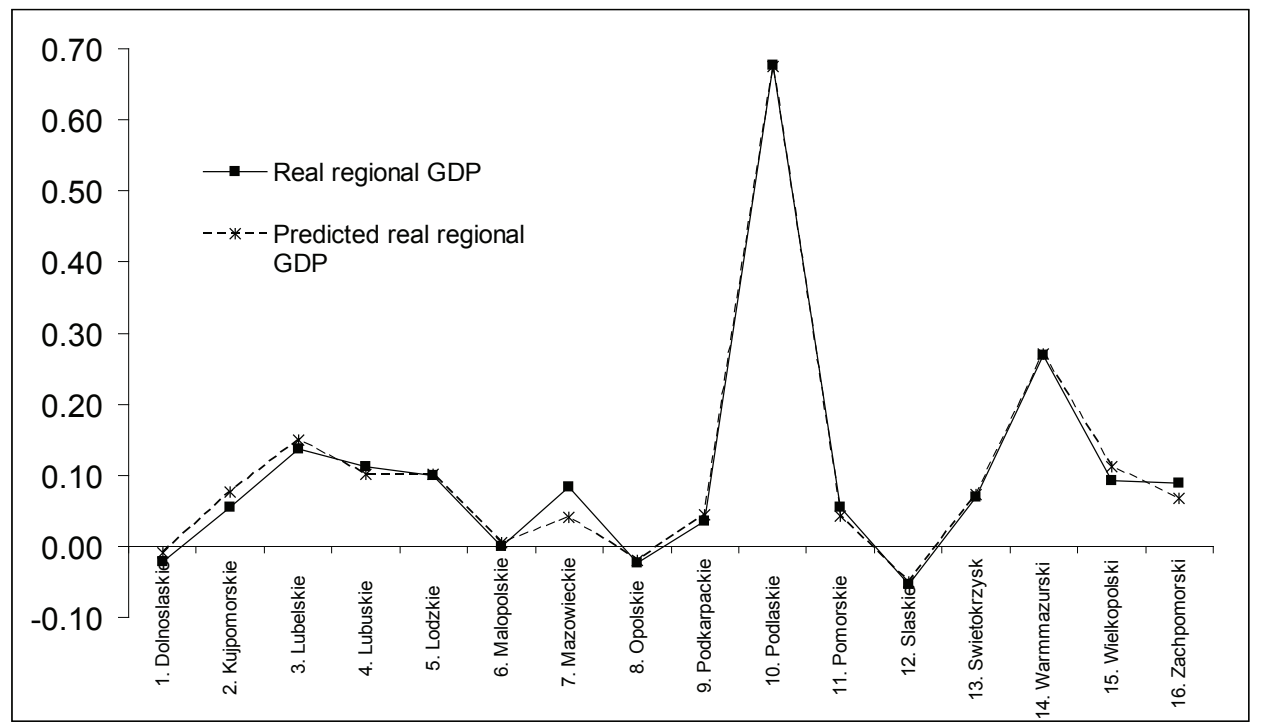

Fig. 2. Real regiona GDP and predicted real regional GDP compared (percentage change from basecase, long-run solution).

Source: Authors' calculations using POLTERM output. Note: Predicted real regional GDP is calculated from the linear regression of the POLTERM result for real regional GDP against region specific LFA / GDP ratios. 


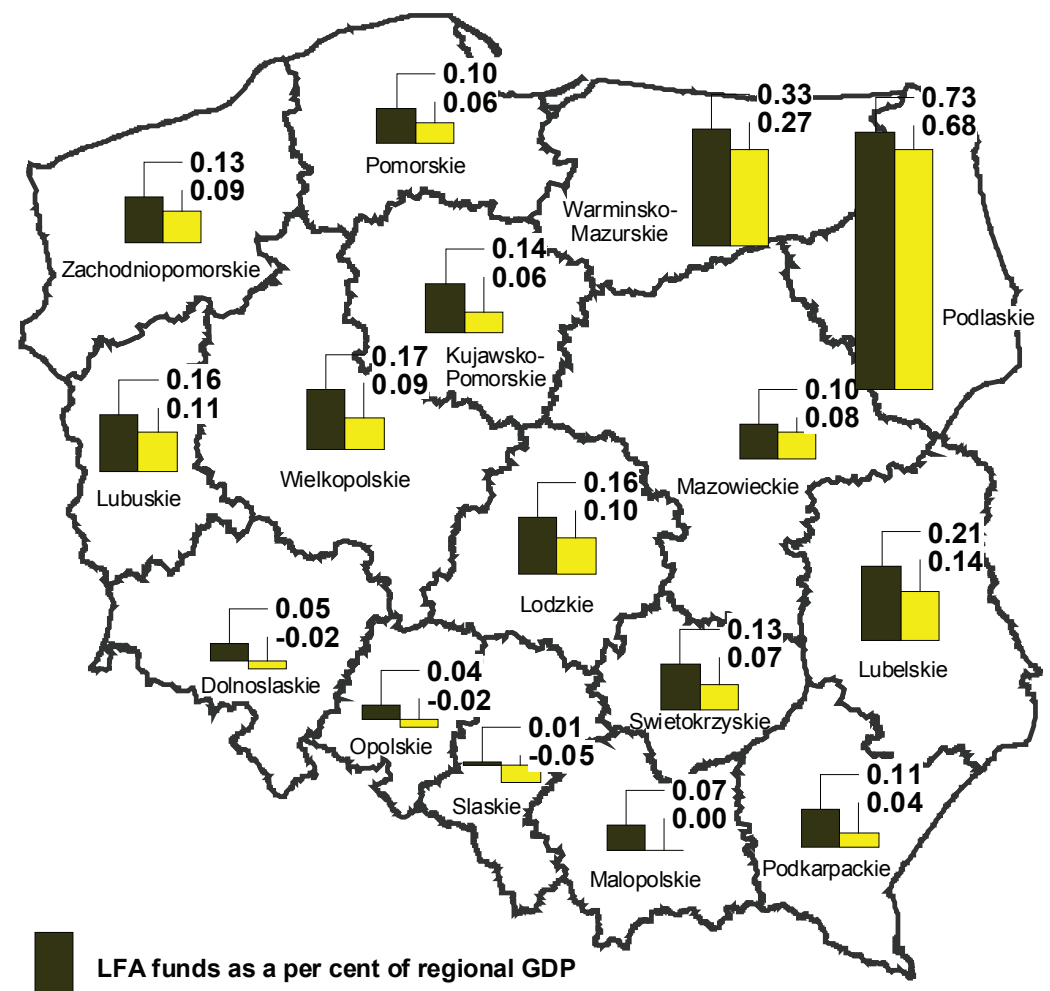

Real GDP percentage change due to LFA funds

Map 1. Regional distribution of LFA funds and LFA impact on regional GDP Source: Authors' calculations using POLTERM output.

As discussed in section on simulation design, national employment is weakly positively related to the real wage. However, despite national employment being endogenous, it remains sufficiently constrained that long-run employment expansion in one Polish region will typically be at the expense of long-run employment in other Polish regions. By expanding land supply and agricultural production in some regions more than others, LFA funds cause a regional redistribution of national employment. In Table 6, we find employment tends to shift from the most urban regions (such as Śląskie, Dolnośląskie, Opolskie) to more rural regions (Podlaskie, Warmińsko-Mazurskie, Lubelskie).

Column 6 of Table 6 reports percentage changes in LFA land supply relative to what it would have been in the absence of the LFA policy. Column 8 reports the percentage change in total agricultural land area by region. Together, these columns show how much land would be released from agricultural use without the LFA policy.

Hence, the results in columns 6 and 8 are a measure of the success of the Polish LFA in meeting its aim of maintaining land in agricultural use. In the absence of the LFA program the region that would release the most land from agricultural use is Podlaskie (row 10), the most agricultural region in Poland (where almost 70 per cent of the rural population works in the agricultural sector). The regions least affected in terms of agricultural land use are Śląskie, Dolnośląskie and Opolskie. These are among the most urban and industrial regions in Poland.

As discussed earlier in reference to Table 5 , it is those traded goods sectors that are not either direct beneficiaries (agriculture producers) or indirect beneficiaries (agricultural processors) of LFA payments that are adversely affected by the program. Of these sectors, it is non-food manufacturing (row 21, Table 5) that experiences the largest output contraction. Table 7 reports output for this sector at the regional level. We find that output for this sector contracts in all regions. However the output contraction is largest in North-Eastern Poland - in Podlaskie by -0.25 and in Warmińsko-Mazurskie by - 0.18 (see Table 7). Yet in column 1 of Table 6 we see that these are the two regions receiving the largest LFA allocations relative to regional GDP. This apparently counter-intuitive result arises from the operation of assumption (iv) in section on simulation design. With labour markets rendered somewhat region-specific via assumption (iv), LFA-induced expansion in agricultural employment is satisfied in part by interregional migration, and in part by employment contraction in other local trade-exposed industries. 
Table 6. Regional impact of LFA support (percentage changes)

\begin{tabular}{|c|c|c|c|c|c|c|c|c|}
\hline \multirow[b]{2}{*}{ Region } & \multirow{2}{*}{$\begin{array}{l}\text { LFA } \\
\text { funds } \\
\text { as a per } \\
\text { cent of } \\
\text { regional } \\
\text { GDP } \\
1\end{array}$} & \multirow[b]{2}{*}{$\begin{array}{l}\text { Real } \\
\text { GDP } \\
2\end{array}$} & \multirow[b]{2}{*}{$\begin{array}{c}\text { Real } \\
\text { Consumption } \\
3\end{array}$} & \multirow[b]{2}{*}{$\begin{array}{c}\text { Employ- } \\
\text { ment } \\
4\end{array}$} & \multirow[b]{2}{*}{$\begin{array}{l}\text { Capital } \\
\text { stock } \\
5\end{array}$} & \multicolumn{3}{|c|}{ Land supply } \\
\hline & & & & & & $\begin{array}{l}\text { LFA } \\
\text { Land } \\
6\end{array}$ & $\begin{array}{c}\text { Non- } \\
\text { LFA } \\
\text { Land } \\
7\end{array}$ & $\begin{array}{c}\text { Total Land } \\
\text { Supply } \\
8\end{array}$ \\
\hline 1. Dolnośląskie & 0.05 & -0.02 & 0.02 & -0.05 & -0.02 & 1.66 & 0 & 0.41 \\
\hline 2. Kujawsko-Pomorskie & 0.14 & 0.06 & 0.20 & 0.01 & 0.05 & 2.96 & 0 & 0.86 \\
\hline 3. Lubelskie & 0.21 & 0.14 & 0.37 & 0.09 & 0.12 & 2 & 0 & 0.98 \\
\hline 4. Lubuskie & 0.16 & 0.11 & 0.29 & 0.05 & 0.10 & 2.08 & 0 & 1.97 \\
\hline 5. Lódzkie & 0.16 & 0.10 & 0.27 & 0.04 & 0.09 & 1.7 & 0 & 1.35 \\
\hline 6. Małopolskie & 0.07 & 0.00 & 0.06 & -0.03 & 0.00 & 2.5 & 0 & 0.73 \\
\hline 7. Mazowieckie & 0.1 & 0.08 & 0.19 & 0.02 & 0.09 & 2.6 & 0 & 2.06 \\
\hline 8. Opolskie & 0.04 & -0.02 & 0.01 & -0.04 & -0.02 & 1.2 & 0 & 0.24 \\
\hline 9. Podkarpackie & 0.11 & 0.04 & 0.15 & 0.00 & 0.03 & 2.1 & 0 & 0.82 \\
\hline 10. Podlaskie & 0.73 & 0.68 & 1.52 & 0.47 & 0.59 & 4.33 & 0 & 4.1 \\
\hline 11. Pomorskie & 0.1 & 0.06 & 0.17 & 0.01 & 0.06 & 2.15 & 0 & 1.59 \\
\hline 12. Śląskie & 0.01 & -0.05 & -0.06 & -0.08 & -0.04 & 0.73 & 0 & 0.11 \\
\hline 13. Świętokrzyskie & 0.13 & 0.07 & 0.21 & 0.02 & 0.06 & 1.6 & 0 & 0.95 \\
\hline 14. Warmińsko-Mazurskie & 0.33 & 0.27 & 0.65 & 0.17 & 0.23 & 2.46 & 0 & 2.08 \\
\hline 15. Wielkopolskie & 0.17 & 0.09 & 0.27 & 0.03 & 0.08 & 2.03 & 0 & 1.2 \\
\hline 16. Zachodniopomorskie & 0.13 & 0.09 & 0.23 & 0.03 & 0.09 & 1.87 & 0 & 1.48 \\
\hline
\end{tabular}

Source: Results from the POLTERM model

Table 7. Changes in manufacturing output by regions (percentage changes)

\begin{tabular}{lc}
\hline 1. Dolnośląskie & -0.12 \\
2. Kujawsko-Pomorskie & -0.14 \\
3. Lubelskie & -0.15 \\
4. Lubuskie & -0.15 \\
5. Lódzkie & -0.14 \\
6. Małopolskie & -0.13 \\
7. Mazowieckie & -0.12 \\
8. Opolskie & -0.11 \\
9. Podkarpackie & -0.15 \\
10. Podlaskie & -0.25 \\
11. Pomorskie & -0.14 \\
12. Śląskie & -0.11 \\
13. Świętokrzyskie & -0.12 \\
14. Warmińsko-Mazurskie & -0.18 \\
15. Wielkopolskie & -0.13 \\
16. Zachodniopomorskie & -0.14 \\
\hline
\end{tabular}

Source: Results from the POLTERM model 


\section{Conclusions}

We analyse the largest EU Rural Development Policy instrument in Poland: support for Less Favoured Areas (LFA). Among the rural development programs of New Member States, LFA is commonly the largest program financed within the Common Agricultural Policy (Gorton et al. 2009). Our modelling suggests that the policy contributes to its ostensible aim - retention of marginal agricultural land use in regions which are predominantly agricultural ${ }^{16}$ and predominantly rural ${ }^{17}$. However, the LFA scheme's contribution to reducing land abandonment appears to be small. The scheme appears most effective in promoting continued land use in intermediate rural ${ }^{18}-$ predomi- $^{\text {- }}$ nantly agricultural types of regions ${ }^{19}$. In these regions, LFA payments cause total land use to be 3 per cent higher than would otherwise have been the case. We found this effect to be much smaller in predominantly urban - intermediate agricultural regions ${ }^{20}$ with total land use only 0.7 per cent higher than it would otherwise have been.

LFA, by promoting the use of marginal agricultural land, also promotes agricultural employment. Since the scheme appears to have its largest effects in predominantly agricultural regions (i.e. regions where more than 50 per cent of the rural population works in agriculture) it appears that it may contribute to one peculiar role played by agricultural policy in general in Poland, namely creating an absorptive buffer for excess agricultural labour (Davidova et al. 2002). As such, the CAP in Poland might act to slow down growth-promoting structural changes by hampering a much needed outflow of people from agriculture to more productive non-agricultural occupations. This is one reason why LFA has been classified as social support rather than development support (Zawalińska 2008).

From an economy-wide perspective, Poland appears a net beneficiary of the LFA program, with the scheme lifting real national consumption by 0.2 per cent. However this macroeconomic outcome masks important impacts on the regional and industrial distribution of economic activity. These distributional impacts are brought about mainly via a Dutch Disease effect, which arises from the fact that the large EU-financed LFA transfers cause the Polish real exchange rate to appreciate. ${ }^{21}$ Since Poland is a net beneficiary of EU support, and mainly due to funds from CAP, in general it is unavoidable that measures such as LFA contribute to real appreciation. However it is the composition of the adversely affected trade-exposed sectors that may concern policy makers. By design, LFA funds tend to flow to agricultural industries in regions that are primarily rural and agricultural. This leaves non-agricultural industries in regions that are primarily urban exposed to the real exchange rate appreciation, while receiving little direct compensation via LFA receipts. At the same time, labour productivity in Polish agriculture remains among the lowest in the EU, at 0.30 compared to an EU15 average of 0.50 (EC 2010). ${ }^{22}$ While not studied directly in this paper, our results for sectoral output raise the important question of whether the LFA program - by discouraging marginal farmers from leaving the land, while simultaneously penalising the trade-exposed high-growth sectors that might otherwise absorb surplus farm labour - could have an adverse impact on Poland's economic growth.

\section{Acknowledgements}

This research was supported by an Australian Group of Eight (Go8) European Fellowship. An earlier stage of the research was supported by the CERGE-EI Foundation under a program of the Global Development Network. The authors are grateful to Glyn Wittwer for his contribution to database design. We thank two anonymous referees for helpful comments on an earlier version of this paper. Any opinions, findings or recommendations in this paper are those of the authors, and do not necessarily reflect views of the aforementioned parties.

\footnotetext{
${ }^{16}$ Regions where more than 50 per cent of the rural population works in agriculture - authors own definition.

${ }^{17}$ Regions where more than 50 per cent of the population lives in rural areas - according to the definition provided by OECD (2011).

${ }^{18}$ Regions where the share of the population living in rural areas is between 15 and 50 per cent - according to the definition provided by OECD (2011)

${ }^{19}$ For a more precise typology of Polish regions see Zawalińska (2009).

${ }^{20}$ The regions where less than 15 per cent of population lives in rural areas and percentage of rural population working in agriculture is between 15-50 per cent.

${ }^{21}$ Early use of the term "Dutch Disease" referred to the contractionary effect on trade-exposed sectors generated by real exchange rate appreciation arising from exogenous increases in resource output or resource prices (Corden and Neary 1982 and Corden 1984). Later studies extended the effect to include the consequences of real appreciation induced by foreign exchange inflows in the form of international aid or loans (see for example Adam and Bevan 2003, Rajan and Subramanian 2005, and Oomes and Kalcheva 2007). These cases are similar to the LFA support studied here. Remittances can also exert significant Dutch Disease effects (Acosta et al. 2009). For Poland, worker remittances are an important source of foreign exchange. For example, in 2007, remittances to Poland were approximately PLN 20.4 b. (EUR 5.4 b.) (NBP 2008: 2), approximately double the size of annual Pillar 2 payments to Poland (see Table 1). Relative to remittances, a factor mitigating the Dutch Disease consequences of LFA payments is the positive effect on resource supply, and hence output. In Table 4, we find that LFA payments increase land supply by approximately 1.2 per cent.

${ }^{22}$ In Poland, the share of agricultural GVA is about 4.3 per cent while the share of employment is 14.7 per cent, hence labour productivity in agriculture is 0.3 . In the EU15 the share of agricultural GVA is 1.7 per cent while the share of employment is 3.4 per cent, hence the labour productivity in agriculture is 0.5 .
} 


\section{References}

Abler, D. 2003. Adjustment at the sectoral level. Paper presented at IAPRAP Workshop on Policy Reform and Adjustment, mimeo, The Wye Campus of Imperial College, October 23-25.

Acosta, P.A., Lartey, E.K. \& Mandelman F.S. 2009. Remittances and the Dutch Disease. Journal of International Economics 79 : 102-116.

Adam, Ch. S. \& Bevan, D.L. 2003. Aid, Public Expenditure and Dutch Disease. Centre for the Study of African Economies, Working Paper 2003-02, Oxford: University of Oxford, 25 p.

ARMA 2009. Monitoring database for Pillar 2 measures. Agency for Reconstruction and Modernization of Agriculture, Warsaw, Poland.

Britz, W. \& Witzke, P. 2008. CAPRI model documentation 2008: Version 2. CAPRI Documentation Paper, 273 p.Cited 24 May 2013. Available on the internet: http://www.capri-model.org/docs/capri_documentation.pdf\#search=\%22CAPREG\%22.

Britz, W. 2012. RegCgeEU+ in GAMS with Graphical User Interface a la CAPRI, CAPRI-RD Project. Deliverable D.3.2.4, University of Bonn, Germany, 58 p.

CC 2009. Commission Communication: Towards a better targeting of the aid to farmers in areas with natural handicaps, European Commission Staff Working Document, 11 p. Brussels 21/04/2009.

Corden, W.M. \& Neary, J.P. 1982. Booming Sector and De-Industrialisation in a Small Open Economy. The Economic Journal 92: $825-48$.

Corden, W.M. 1984. Booming Sector and Dutch Disease. Economic Survey and Consolidation. Oxford Economic Papers, 36(3): 359-380.

Costa, C., Osborne, M., Zhang, Z., Boulanger, P. \& Jomini, P. 2009. Modelling the Effects of the EU Common Agricultural Policy. Staff Working Paper. Productivity Commission, Australian Government, Melbourne, December 2009. Cited 20 April 2013. Available on the Internet: http://www.pc.gov.au/_data/assets/pdf_file/0005/92777/european-agricultural-policy.pdf

Davidova, S., Gorton, M. Ratinger, T., Zawalinska, K., Iraizoz, B., Kovacs, B. \& Mizo, T. 2002. Variations in Farm Performance: Evidence from the CEECS and Existing EU Member States, In: European Association of Agricultural Economists, International Congress, August 28-31, 2002, 18 p. Zaragoza, Spain.

Dixon, J. \& Matthews, A. 2006. Impact of the 2003 Mid-Term Review of the Common Agricultural Policy. Economic and Social Research Institute Quarterly Economic Commentary. Spring: 36-52.

Dixon, P.B., Parmenter, B.R., Powell A.A. \& Wilcoxen P.J. 1992. Notes and problems in applied general equilibrium analysis. Amsterdam: North-Holland, $392 \mathrm{p}$.

EC 2009a. Commission Communication: Towards a better targeting of the aid to farmers in areas with natural handicaps, European Commission Staff Working Document, Brussels 21/04/2009.

EC 2009b. Citizens' summary of the Commission Communication "Towards a better targeting of the aid to farmers in areas with natural handicaps", Cited 20 April 2013. Available on the Internet: http://ec.europa.eu/agriculture/rurdev/lfa/comm/citizensum_en.pdf

EC 2010. Rural Development In The European Union Statistical and Economic Information. Report 2010, DG AGRI, December, Brussels.

EC 2011. Impact Assessment Common Agricultural Policy Towards 2020, Annex 3, Commission Staff Working Paper, 12 October, Brussels.

EUROSTAT 2004. Minimum Wages EU Member States, Candidate Countries and the US in 2004, Brussels. Cited 20 April 2013. Available on the Internet: http://epp.eurostat.ec.europa.eu/cache/ITY_OFFPUB/KS-NK-04-010/EN/KS-NK-04-010-EN.PDF

EUROSTAT 2011. Link to Input-Output tables. Cited 20 April 2013. Available on the Internet: http://epp.eurostat.ec.europa.eu/ portal/page/portal/esa95_supply_use_input_tables/data/workbooks

FDPA 2010. Rural Poland 2010. Rural Development Report. Foundation for the Polish Agriculture, Warsaw, Poland. Cited 20 April 2013. Available on the Internet: http://www.fdpa.org.pl/?option=com_content\&view=article\&id=471\&ltemid=36

Gelan, A. \& Schwarz, G. 2008. The effect of single farm payments on less favoured areas agriculture in Scotland: a CGE analysis. Agricultural and Food Science 17: 3-17.

Gorton, M., Hubbard, C., \& Hubbard, L. 2009. The Folly of European Union Policy Transfer: Why the Common Agricultural Policy (CAP) Does Not Fit Central and Eastern Europe. Regional Studies, 43:1305-1317.

GUS 2005. Statistical Yearbook of the Regions - Poland, Main Statistical Office, Warsaw.

GUS 2009a. Supply and Use table in 2005, June 2009, Main Statistical Office, Warsaw.

GUS 2009b. Input-Output Table At Basic Prices In 2005, September 2009, Main Statistical Office, Warsaw

GUS 2009c. Information about scale and directions of emigration from Poland over 2004-2008 [Informacja o rozmiarach i kierunkach emigracji z Polski w latach 2004-2008]. Polish Main Statistical Office, Warsaw. Cited 20 April 2013. Available on the Internet: http://www.stat.gov.pl/cps/rde/xbcr/gus/PUBL_lud_infor_o_rozm_i_kierunk_emigra_z_polski_w_latach_2004_2008.pdf

GUS 2010. Wages and salaries, Main Statistical Office electronic resources, Warsaw. Cited 20 April 2013. Available on the Internet: http://www.stat.gov.pl/gus/5840_1630_PLK_HTML.htm

GUS-BDR 2009. Bank of Regional Data (Bank Danych Regionalnych). Main Statistical Office regional data base. Cited 20 April 2013. Available on the Internet: http://www.stat.gov.pl/bdl/app/strona.html?p_name=indeks

Honkatukia, J., Kinnunen, J. \& Marttila, K. 2009. Anticipating the Regional Effects of an Ageing Population: A Dynamic CGE Analysis for Finland. Conference paper presented at the 12th Annual Conference on Global Economic Analysis, Santiago, Chile, GTAP source 3136 . 
K. Zawalińska et al. (2013) 22: 272-287

Horridge, J.M., Madden J.R. \& Wittwer, G. 2005. Impact of the 2002-03 Drought on Australia, Journal of Policy Modeling, 27(3): 285-308

Horridge, M. 2011. The TERM model and its data base.CoPS/IMPACT Working Paper, No. G-219, July 2011.

IEEP 2006. An Evaluation of the Less Favoured Area Measure in the 25 Member States of the European Union. Institute for European Environmental Policy, London.

Kinnunen, J., Marttila, K. \& Honkatukia, J. 2009. Väestön ikääntymisestä johtuvien julkisten kulutusmenojen kasvun rakenteelliset vaikutukset, Government Institute for Economic Research (VATT), Research Report 147, Helsinki. (in Finnish).

Klepacka-Kołodziejska, D. 2010. Does Less Favoured Areas Measure support sustainability of European rurality? The Polish experience. Rural Areas and Development, Vol. 7: 121-134.European Rural Development Network Studies.

Lambarraa, F. \& Kallas, Z. 2009. Subsidies and technical efficiency: An application of stochastic frontier and Random-effect Tobit models to LFA Spanish olive farms. In: European Association of Agricultural Economists, 113th Seminar, September 3-6, 2009, 12 p. Chania, Crete, Greece.

Latruffe, L. \& Le Mouel, Ch. 2009 Capitalization of government support in agricultural land prices: what do we know? Journal of Economic Survey, 23: 659-691.

Lehtonen, H. 2008. Resolving the conflict between environmental damage and agricultural viability on less favoured areas. In: European Association of Agricultural Economists, International Congress, August 26-29, 2008, 9 p. Ghent, Belgium.

LFA 2012. Website of the European Commission DG AGRI. Cited 20 April 2013. Available on the Internet: http://ec.europa.eu/ agriculture/statistics/rural-development/2012/ch34_en.pdf

MARD 2006. National Strategic Plan for 2007-2013 Rural Development. Polish Ministry of Agriculture and Rural Development, August 2006, Warsaw.

MARD 2009. Ex-post evaluation of RDP 2004-2006. Polish Ministry of Agriculture and Rural Development, June 2009, Warsaw.

NBP 2008. New estimation method of labour income from abroad in the balance of payments statistics, National Bank of Poland, Department of Statistics. Cited 23 April 2013. Available on the Internet: http://www.nbp.pl/en/statystyka/bilans_platniczy/ doch_en.pdf

Nowicki P., Hart, K. van Meij, H., Baldock, D., Banse, M. Bartley, J., van Bommel, K., Helming, J. Jansson, K., Jansson, T., Terluin, I., van der Veen, H. Verburg Alterra, P., Verhoog, D. \& Woltjer, G. 2009. Study on the economic, social and environmental impact of the modulation provided for in Article 10 of Council Regulation (EC) No 1782/2003. Directorate General for Agriculture and Rural Development, Contract Nr 30-CE-0162480/00-47, LEI, The Hague - IEEP, London.

OECD 2011. OECD Regional Typology. Directorate for Public Governance and Territorial Development, Paris, France.

OJ 2003. Special Report concerning rural development: support for less-favoured areas, together with the Commission's replies. European Court of Auditors No 4/2003, Official Journal of the European Union, OJ C 151 of 27 June 2003. Cited 20 April 2013. Available on the Internet: http://eca.europa.eu/portal/pls/portal/docs/1/173294.PDF

Oomes, N. \& Kalcheva, K. 2007. Diagnosing Dutch disease: does Russia have the symptoms? BOFIT Discussion Papers No.7, Helsinki, 42 p. Rajan, R.G. \& Subramanian, A. 2005. What Undermines Aid's Impact on Growth?. IMF Working Papers 05/126, Warshington: International Monetary Fund, $55 \mathrm{p}$.

RDP (2007-2013) 2007. Rural Development Programme 2007-2013, Polish Ministry of Agriculture and Rural Development, July 2007, Warsaw, $384 \mathrm{p}$.

Schouten, M.A.H., Gaaff,A. \& Heijman, W.J.M. 2009. Less favoured area measure in the Netherlands: a welcome or negligible addition? Applied Studies in Agribusiness and Commerce Vol. 3, No 1-2.

Schwarz, G. 2010. Contribution of LFA agriculture to the Scottish economy: a SAM based analysis of intersectoral linkages. Management theory and studies for rural business and infrastructure development, No. 22(3). Research Papers, 22 p.

Tödtling-Schönhofer, H., Schuh, B., Lukesch, R., Vercruysse, J-P, Wimmer, H., Elbe, S., Soto, P. Wortmann. L. 2008. Synthesis of Ex Ante Evaluations of Rural Development Programmes 2007-2013, Final Report and Annexes. Metis and AEiDL for European Commission, Brussels, $233 \mathrm{p}$.

Törmä, H., Zawalinska, K., Blanco-Fonseca, M., Ferrari, E. \& Jansson, T. 2010. Regional CGE model layout with a focus on integration with the partial equilibrium models and modelling of RD measures, CAPRI-RD Project Deliverable 3.2.1 Model development and adaptation - Regional CGEs, 28 p.

van Meijl, H., van Rheenen, T. \& Tabeau, A. 2006. The impact of different policy environments on agricultural land use in Europe. Agriculture, Ecosystem and Environment 114:21-38.

Witzke P. \& Britz W. 2010. Report on modelling RD measures in CAPRI, CAPRI-RD Project Deliverable 3.1.2, Univeristy of Bonn, Germany, $14 p$.

Woltjer, G., Bezlepkina, I., van Leeuwen, M., Helming, J., Bunte, F., Buisman, E., Luesink, H., Kruseman, G., Polman, N., van der Veen, H. \&Verwaart, T. 2011. The agricultural world in equations. An overview of the main models used at LEI, LEI Memorandum 11-151, Wageningen UR, The Hague, Netherlands. Cited 20 April 2013. Available on the Internet: http://www.lei.dlo.nl/publicaties/PDF/2011/11-151.pdf.

Zawalińska, K. 2009. Instrumenty i efekty wsparcia Unii Europejskiej dla regionalnego rozwoju obszarów wiejskich w Polsce. IRWiR PAN, Warsaw, Poland. 368 p.(in Polish with English summary) Cited 24 May 2013. Available on the Internet: http://www.irwirpan.waw.pl/polski/Katarzyna_Zawalinska-Instrumenty_i_efekty_wsparcia_Unii_Europejskiej_dla_regionalnego_rozwoju_obszarow_wiejskich_w_Polsce.pdf

Zawalińska, K. 2008. Ile jest spójności a ile efektywności w polityce rozwoju obszarów wiejskich w Polsce. Wieś i Rolnictwo 139: 43-56. (in Polish with English abstract). Cited 24 May 2013. Available on the Internet: http://www.ceeol.com/aspx/issuedetails. aspx?issueid=fe4d1daf-dddd-4267-8c07-c0ebd050b1fa\&articleid=e7c4c864-87fd-4c29-bf18-7d8f10ad0593\#ae7c4c864-87fd4c29-bf18-7d8f10ad0593 